Research article

\title{
Runoff initiation, soil detachment and connectivity are enhanced as a consequence of vineyards plantations
}

\author{
A. Cerdà ${ }^{\mathrm{a},{ }^{*}}$, S.D. Keesstra ${ }^{\mathrm{b}, \mathrm{c}}$, J. Rodrigo-Comino ${ }^{\mathrm{d}, \mathrm{e}}$, A. Novara $^{\mathrm{f}}$, P. Pereira ${ }^{\mathrm{g}}$, E. Brevik ${ }^{\mathrm{h}}$, \\ A. Giménez-Morera ${ }^{\mathrm{i}}$, M. Fernández-Raga ${ }^{\mathrm{j}}$, M. Pulido ${ }^{\mathrm{k}}$, S. di Prima ${ }^{1}$, A. Jordán ${ }^{\mathrm{m}}$ \\ a Soil Erosion and Degradation Research Group, Department of Geography, Valencia University, Blasco Ibàñez, 28, 46010 Valencia, Spain \\ b Soil Physics and Land Management Group, Wageningen University, Droevendaalsesteeg 4 6708PB, Wageningen, The Netherlands \\ ${ }^{\mathrm{c}}$ Civil, Surveying and Environmental Engineering, The University of Newcastle, Callaghan 2308, Australia \\ d Department of Physical Geography, Trier University, D-54286 Trier, Germany \\ e Instituto de Geomorfología y Suelos, Department of Geography, Málaga University, Campus of Teatinos S/n, 29071 Málaga, Spain \\ ${ }^{\mathrm{f}}$ Dipartimento di Scienze Agrarie e Forestali, University of Palermo, Italy \\ ${ }^{g}$ Department of Environmental Policy, Mykolas Romeris University, Ateities g. 20, LT-08303 Vilnius, Lithuania \\ ${ }^{\mathrm{h}}$ Department of Natural Sciences, Dickinson State University, EEUU, United States \\ i Departamento de Economi; a y Ciencias Sociales, Escuela Politécnica Superior de Alcoy, Universidad Politécnica de Valencia, Paseo Del Viaducto, 1, 03801 \\ Alcoy, Alicante, Spain \\ ${ }^{\mathrm{j}}$ Department of Physics, University of Leon, Spain \\ ${ }^{\mathrm{k}}$ GeoEnvironmental Research Group, University of Extremadura, Faculty of Philosophy and Letters, Avda. de La Universidad S/n, 10071 Cáceres, Spain \\ ${ }^{1}$ Dipartimento di Agraria, Università Degli Studi di Sassari, Viale Italia 39, 07100 Sassari, Italy \\ m MED_Soil Research Group, Department of Crystallography, Mineralogy and Agricultural Chemistry, University of Seville, Profesor García González, 1, 41012 \\ Sevilla, Spain
}

\section{A R T I C L E I N F O}

\section{Article history:}

Received 30 April 2017

Received in revised form

14 July 2017

Accepted 15 July 2017

\section{Keywords:}

Erosion

Connectivity

Water

Sediments

Detachment

Rainfall simulation

\begin{abstract}
A B S T R A C T
Rainfall-induced soil erosion is a major threat, especially in agricultural soils. In the Mediterranean belt, vineyards are affected by high soil loss rates, leading to land degradation. Plantation of new vines is carried out after deep ploughing, use of heavy machinery, wheel traffic, and trampling. Those works result in soil physical properties changes and contribute to enhanced runoff rates and increased soil erosion rates. The objective of this paper is to assess the impact of the plantation of vineyards on soil hydrological and erosional response under low frequency - high magnitude rainfall events, the ones that under the Mediterranean climatic conditions trigger extreme soil erosion rates. We determined time to ponding, Tp; time to runoff, Tr; time to runoff outlet, Tro; runoff rate, and soil loss under simulated rainfall $\left(55 \mathrm{~mm} \mathrm{~h}^{-1}, 1 \mathrm{~h}\right)$ at plot scale $\left(0.25 \mathrm{~m}^{2}\right)$ to characterize the runoff initiation and sediment detachment. In recent vine plantations ( $<1$ year since plantation; $R$ ) compared to old ones ( $>50$ years; 0 ). Slope gradient, rock fragment cover, soil surface roughness, bulk density, soil organic matter content, soil water content and plant cover were determined. Plantation of new vineyards largely impacted runoff rates and soil erosion risk at plot scale in the short term. $\mathrm{Tp}, \mathrm{Tr}$ and Tro were much shorter in $\mathrm{R}$ plots. $\mathrm{Tr}$ $\mathrm{Tp}$ and Tro-Tr periods were used as connectivity indexes of water flow, and decreased to 77.5 and $33.2 \%$ in $\mathrm{R}$ plots compared to $\mathrm{O}$ plots. Runoff coefficients increased significantly from $\mathrm{O}(42.94 \%)$ to $\mathrm{R}$ plots (71.92\%) and soil losses were approximately one order of magnitude lower (1.8 and $12.6 \mathrm{Mg} \mathrm{ha}^{-1} \mathrm{~h}^{-1}$ for $\mathrm{O}$ and $\mathrm{R}$ plots respectively). Soil surface roughness and bulk density are two key factors that determine the increase in connectivity of flows and sediments in recently planted vineyards. Our results confirm that plantation of new vineyards strongly contributes to runoff initiation and sediment detachment, and those findings confirms that soil erosion control strategies should be applied immediately after or during the plantation of vines.
\end{abstract}

๑) 2017 Elsevier Ltd. All rights reserved.

\footnotetext{
* Corresponding author.

E-mail addresses: artemio.cerda@uv.es (A. Cerdà), saskia.keesstra@wur.nl (S.D. Keesstra), rodrigo-comino@uma.es (J. Rodrigo-Comino), agata.novara@unipa.it (A. Novara),

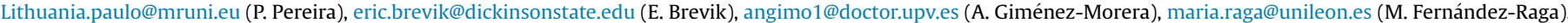
mapulidof@unex.es (M. Pulido), simoedg@gmail.com (S. di Prima), ajordan@us.es (A. Jordán).
} 


\section{Introduction}

Soil erosion is one of the main environmental risks in agricultural land around the world, and specifically, in vineyard soils. This has been well documented in Mediterranean terroirs (Prosdocimi et al., 2016a; Kirchhoff et al., 2017), as it leads to loss of soil fertility, soil quality and production of food, fibers, biomass and services (Sabatier et al., 2014; Vaudour et al., 2017). Enhanced runoff flow generation reported in agricultural soils also contributes to flood (Martínez-Casasnovas et al., 2005) and water pollution risk (Serpa et al., 2017).

Different authors have observed that vineyards are among the soil uses that contribute most to soil erosion in Mediterranean areas, mainly due to climate conditions, relief, poor organic matter content (Muñoz-Rojas et al., 2012; Novara et al., 2011) and soil tillage and management (Rodrigo Comino et al., 2016a; Ki). Many studies have reported higher soil loss values in vineyards all through the Mediterranean basin, exceeding the threshold suggested for tolerable erosion rates in Europe, about $1.4 \mathrm{Mg} \mathrm{ha}^{-1}$ year $^{-1}$ (Verheijen et al., 2009). Different authors have quantified the beneficial impact of soil erosion control measures in vineyard soils (Arnáez et al., 2007; Morvan et al., 2014; Novara et al., 2011; Prosdocimi et al., 2016b; Raclot et al., 2009; Ramos et al., 2007) but it is necessary to find the causes of the high erosion rates to plan a proper strategy to achieve a sustainable management.

Usually, plantation of vines and orchards takes place every $10-50$ years and around $5 \%$ of the land is under plantations works yearly. Moreover, within the European Union (EU), the CAP (Common Agriculture Policy) subsidized the substitution of certain crops in order to renew and improve the varieties cropped, promoting new fruit and vine plantations, and this encourage the removal of old plantations and establishment of new ones. Little is know about the environmental impact of those policies, which are funded by the EU with $50 \%$ of the cost. Vine plantation is carried out after deep ploughing, using heavy machinery and trampling, causing deep impacts in soil physical properties. In vulnerable soils, compaction of the top layer and soil sealing contribute to decreased infiltration rates, enhanced runoff generation and increased soil erosion risk.

This work aims to the study of the impact of plantation of vineyards on soil hydrological response and soil loss rates in Eastern Spain. To fill this gap, the objectives of this paper are: [i] to study runoff initiation by means of measurements of the time to ponding, time to runoff and time to runoff outlet in $0.25 \mathrm{~m}^{2}$ plot surfaces, which will inform about the connectivity of flows; [ii] runoff and soil erosion rates under simulated rainfall $\left(55 \mathrm{~mm} \mathrm{~h}^{-1}\right.$, $1 \mathrm{~h}, 0.25 \mathrm{~m}^{2}$ contributing area); [iii] and assessment of the role slope angle, rock fragment cover, soil roughness, bulk density, soil organic matter, soil moisture and plant cover on runoff initiation and soil erosion in tillage vineyards. The research strategy applied was a paired plot approach: in recent vine plantations $(<1$ year since plantation) compared to old ones ( $>50$ years). The research was applied on soils developed on marls and on soils developed on a Limestone slope colluvium that are the two ones found in the Les Alcusses valley.

\section{Material and methods}

\subsection{Study site}

Les Alcusses Valley is located in Eastern Spain (Valencia Province) and the research sites are placed close to the Celler del Roure and Pago Casa Gran wineries which produce Monastrell and Riesling grape varieties, respectively, in the Moixent municipality (Valencia, Eastern Spain), at $38.816{ }^{\circ} \mathrm{N} ; 0.810^{\circ} \mathrm{E}, 560 \mathrm{~m}$ a.s.l. (Fig. 1). Mean annual rainfall is $450 \mathrm{~mm}$ and average mean temperature is $15^{\circ} \mathrm{C}$.
The vineyards are located on Cretaceous limestones (hills) and Eocene marls (valley bottom), as well as on colluvium at the base of hillslopes. The upper part of the hills is covered with pine forest (Pinus halepensis) and shrubs (Quercus coccifera and Juniperus oxycedrus, mostly), which are used as rangelands. Two research sites were selected on soils located at the lower slope positions (colluvium), with sandy loam soils with very high rock fragment content: Celler del Roure (CR) and La Bastida (LB). Two more research sites were selected at the valley (marls), on clayey soils: Pago Casa Gran (CG) and Les Alcusses (LA). At each site, ten paired plots were selected with old $(\mathrm{O} ;>50$ years) and recently planted vineyards $(\mathrm{R}$; $<1$ year) (Fig. 2). The total number of plots was 80 ( 4 sites $\times 2$ O/R types $\times 10$ plots).

\subsection{Soil analysis and plot characteristics}

Plant cover, rock fragment cover and roughness coefficient were measured previously to rainfall experiments. Plant and rock fragment cover were determined by measuring presence (1) or absence (0) in 100 points regularly distributed at each $0.25 \mathrm{~m}^{2}$ plot and the total amount of 1-values was consider representative of each plot. Roughness of the soil surface was determined in four $55-\mathrm{cm}$ long adjacent transects located at the north, south, east and west of each plot using a 1-m long chain. The chain was carefully placed on the irregular soil surface and the roughness coefficient $\left(\mathrm{m} \mathrm{m}^{-1}\right)$ was calculated as the total length of the chain distributed over a horizontal distance of $55 \mathrm{~cm}$. Soil samples $(0-20 \mathrm{~mm})$ were collected in points a few centimetres downslope from each study plot and soil water content (\%) was measured on a weight basis after drying samples $\left(105^{\circ} \mathrm{C}, 24 \mathrm{~h}\right)$. Soil organic matter was determined by the Walkley-Black method (Walkley and Black, 1934). Bulk density was measured by the ring method for the $0-60 \mathrm{~mm}$ soil layer.

\subsection{Rainfall simulation experiments}

Eighty rainfall simulation experiments $(4$ sites $\times 2$ parent materials $\times 10$ plots) were carried out at $55 \mathrm{~mm} \mathrm{~h}^{-1}$ rainfall intensity for $1 \mathrm{~h}$ on circular paired plots $\left(0.55 \mathrm{~m}\right.$ in diameter, $\left.0.25 \mathrm{~m}^{2}\right)$. Rainfall intensities about $55 \mathrm{~mm} \mathrm{~h}^{-1}$ have a return period of 5 years (Elías Castillo and Ruiz Beltran, 1979). In order to avoid inter-annual variability in the soil moisture and allow the comparison between study sites, all experiments were carried out when the soil moisture (weight ratio) was low, during the typical Mediterranean summer drought (July 2012, 2013, 2014 and 2015) and after a minimum period of 32 dry (no rainfall events) days. At each plot, runoff flow was collected at 1-min intervals and water volume was measured. Runoff coefficient was calculated as the percentage of rainfall water running out the circular plot without infiltrating. Runoff samples were desiccated $\left(105^{\circ} \mathrm{C}, 24 \mathrm{~h}\right)$ and sediment yield was calculated on a weight basis in order to calculate soil loss per area and time $\left(\mathrm{Mg} \mathrm{ha}^{-1} \mathrm{~h}^{-1}\right)$. Sediment concentration in the runoff was measured each $5 \mathrm{~min}$ and determined by desiccation. During rainfall simulation experiments, time to ponding (time required for $50 \%$ of the surface to be ponded; $\mathrm{Tp}, \mathrm{s}$ ), time to runoff initiation ( $\mathrm{Tr}$, s) and time required by runoff to reach the outlet (Tro, s) were recorded. Tp was determined when ponds were found and Tr when those ponds were communicated by the runoff. Tr-Tp and Tro- $\mathrm{Tr}$ were calculated and they indicate how the ponding is transformed into runoff and how much the runoff in the soil surface last to reach the plot outlet. More information about the use of rainfall simulators can be found in Keesstra et al. (2016) and Rodrigo Comino et al. (2016b). 


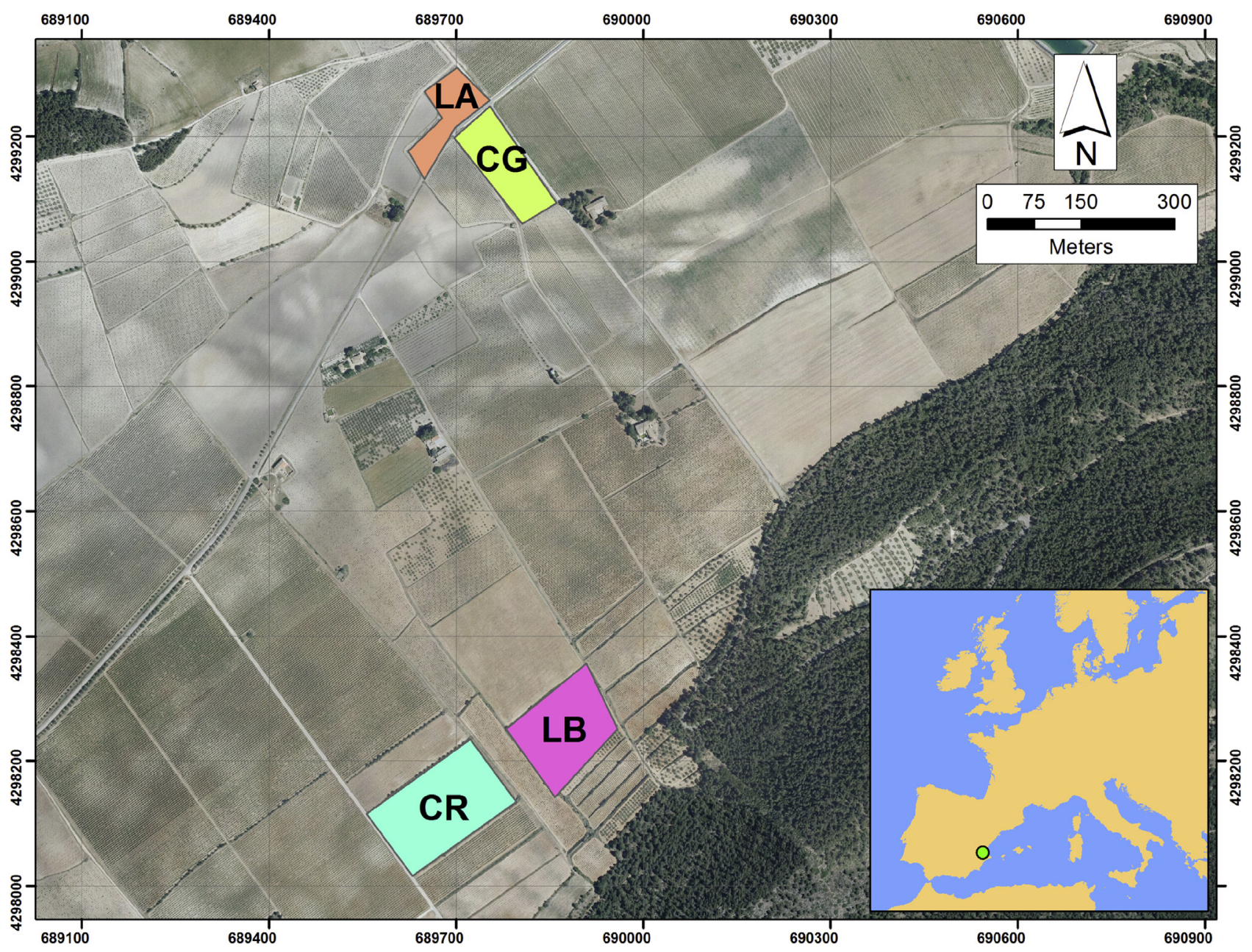

Fig. 1. Study area. CG: Pago Casa Gran; CR: Celler del Roure; LA: Les Alcusses; LB: La Bastida.
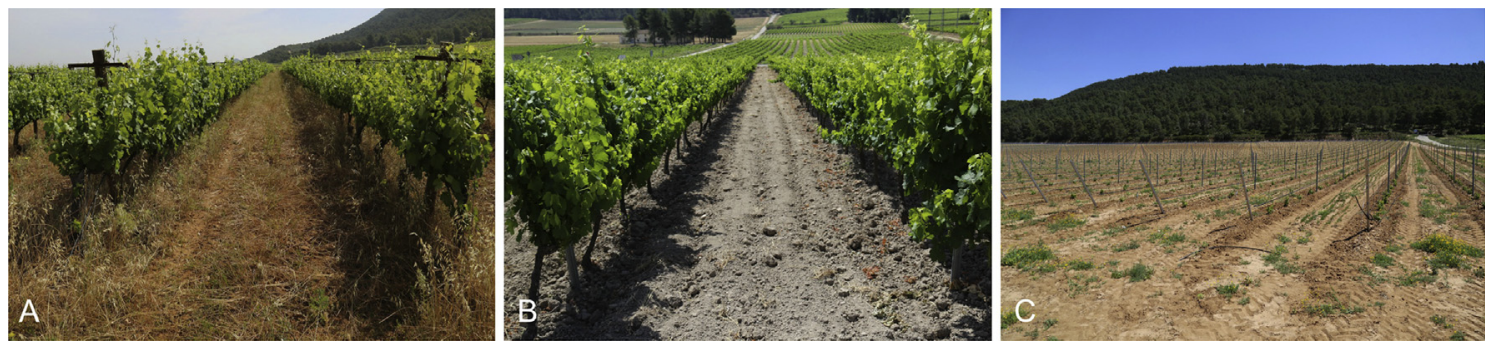

Fig. 2. View of studied old vineyards ( $>25$ years) sites in Celler del Roure (A) and Les Alcusses (B) and a recently planted vineyard ( $<1$ year) in La Bastida (C).

\subsection{Statistical analysis}

The normal distribution of data was checked using the ShapiroWilk test. As the null hypothesis was rejected in most cases, nonparametric statistics and tests were used. The Kruskal-Wallis ANOVA test (K-W) was used to find differences among study sites and type of plots. When significant differences were found, a post-hoc test was used to find homogenous groups (Bonferroni test). The Mann-Whitney $U$ test was used to find differences between plot types (old or recently planted vines). Spearman's rank correlation coefficient (Rs) was used to analyse possible relations between variables. Tests were carried out using Statgraphics Centurion XVI (StatPoint, 1982-2013) and Statistica 10.0 (StatSoft,
2010) software packs.

\section{Results}

\subsection{Soil surface properties}

Although soil slope varied significantly among sites (K-W, $\mathrm{p}<0.0001)$, with relatively gentle slope at CR (4-9\%) and CG (6-9\%), and deeper slope in LB (11-18\%) and LA (10-16\%), no differences were observed between $\mathrm{O}$ and $\mathrm{R}$ plots $(\mathrm{M}-\mathrm{W} \mathrm{U}, \mathrm{p}>0.05$; Table 1). Rock fragment cover varied (K-W, p $<0.0001)$ between sites located on clayey marls ( $0-2 \%$ in CG and $0-4 \%$ in LA) and colluvium from limestone hillslopes (5-15\% in CR and $24-79 \%$ in 
Table 1

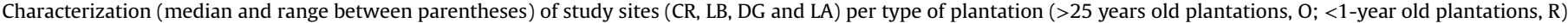

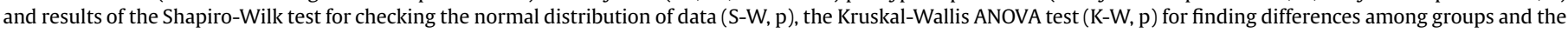

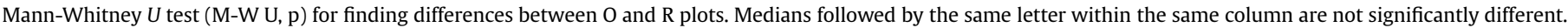
ND: not determined.

\begin{tabular}{|c|c|c|c|c|c|c|c|c|}
\hline Type & Site & Slope (\%) & $\begin{array}{l}\text { Rock fragment cover } \\
(\%)\end{array}$ & $\begin{array}{l}\text { Roughness coefficient (m } \\
\mathrm{m}^{-1} \text { ) }\end{array}$ & $\begin{array}{l}\text { Bulk density ( } \mathrm{g} \\
\mathrm{cm}^{-3} \text { ) }\end{array}$ & $\begin{array}{l}\text { Soil organic matter } \\
\text { (\%) }\end{array}$ & $\begin{array}{l}\text { Soil water content } \\
(\%)\end{array}$ & $\begin{array}{l}\text { Plant cover } \\
(\%)\end{array}$ \\
\hline \multirow[t]{5}{*}{$\mathrm{O}$} & CG & $7(6,9) \mathrm{a}$ & $1(0,2) \mathrm{a}$ & $1.47(1.37,1.54) \mathrm{b}$ & $1.11(1.01,1.16) \mathrm{a}$ & $1.60(1.40,1.98) \mathrm{c}$ & $6.88(5.87,7.54) \mathrm{cd}$ & $6.5(4,9) \mathrm{cd}$ \\
\hline & CR & $6(4,9) \mathrm{a}$ & $13.5(12,15) \mathrm{c}$ & $1.49(1.34,1.67) \mathrm{b}$ & $1.06(1.01,1.20) \mathrm{a}$ & $1.27(1.04,1.48) \mathrm{ab}$ & $5.66(4.65,8.44) a b c$ & $4(3,6) a b c$ \\
\hline & LA & $13(12,15) b$ & $1(0,4) \mathrm{ab}$ & $1.46(1.39,1.67) \mathrm{b}$ & $1.22(1.14,1.30) \mathrm{b}$ & $1.54(1.43,1.87) \mathrm{c}$ & $8.16(7.45,8.93) d$ & $7(5,9) d$ \\
\hline & LB & $14(11,18) b$ & $61(48,79) \mathrm{e}$ & $1.50(1.32,1.65) \mathrm{b}$ & $1.18(1.01,1.23) \mathrm{ab}$ & $1.44(1.05,1.82) b c$ & $5.49(5.13,5.98)$ bcd & $5.5(3,8)$ bcd \\
\hline & $\begin{array}{l}\text { All } \\
\text { sites }\end{array}$ & $10(4,18)$ & $8(0,79)$ & $1.48(1.32,1.67)$ & $1.13(1.01,1.30)$ & $1.48(1.04,1.98)$ & $6.6(4.65,8.93)$ & $6(3,9)$ \\
\hline \multirow[t]{5}{*}{$\mathrm{R}$} & CG & $7.5(6,9) \mathrm{a}$ & $1(0,2) \mathrm{a}$ & $1.24(1.09,1.32) \mathrm{a}$ & $1.38(1.34,1.46) \mathrm{c}$ & $1.49(1.32,1.76) b c$ & $6.40(4.97,6.93) \mathrm{bcd}$ & $5(2,7)$ abcd \\
\hline & CR & $6(4,8) a$ & $7(5,9) b$ & $1.13(1.04,1.32) \mathrm{a}$ & $1.46(1.35,1.67) \mathrm{c}$ & $1.06(0.76,1.45) \mathrm{a}$ & $5.28(4.65,6.43) \mathrm{b}$ & $4(1,7) \mathrm{ab}$ \\
\hline & LA & $14(10,16) \mathrm{b}$ & $1(0,4) a b$ & $1.15(1.09,1.19) \mathrm{a}$ & $1.47(1.41,1.57) \mathrm{c}$ & $1.45(1.23,1.64) b c$ & $6.65(5.87,6.89) \mathrm{cd}$ & $5(2,7) a b c$ \\
\hline & LB & $13.5(11,17)$ & $34(24,44) d$ & $1.20(1.15,1.26) \mathrm{a}$ & $1.44(1.34,1.65) \mathrm{c}$ & $1.06(0.98,1.23) \mathrm{a}$ & $4.33(2.74,4.87) \mathrm{a}$ & $3(1,5) \mathrm{a}$ \\
\hline & $\begin{array}{l}\text { All } \\
\text { sties }\end{array}$ & $9.5(4,17)$ & $4.5(0,44)$ & $1.17(1.04,1.32)$ & $1.45(1.34,1.67)$ & $1.25(0.76,1.76)$ & $5.80(2.74,6.93)$ & $4(1,7)$ \\
\hline S-W, p & & $1.43 \times 10^{-5}$ & 0.0 & $3.69 \times 10^{-5}$ & $2.01 \times 10^{-4}$ & 0.1463 & 0.6363 & 0.0100 \\
\hline $\mathrm{K}-\mathrm{W}, \mathrm{p}$ & & $5.75 \times 10^{-11}$ & $1.03 \times 10^{-12}$ & $5.49 \times 10^{-11}$ & $1.00 \times 10^{-11}$ & $4.55 \times 10^{-8}$ & $1.67 \times 10^{-10}$ & $1.16 \times 10^{-5}$ \\
\hline $\begin{array}{c}\mathrm{M}-\mathrm{W} \mathrm{U} \\
\mathrm{p}\end{array}$ & & $>0.05$ & $>0.05$ & 0 & 0 & $6.65 \times 10^{-4}$ & $7.56 \times 10^{-4}$ & $8.81 \times 10^{-5}$ \\
\hline
\end{tabular}

LB), but no differences were observed between $\mathrm{O}$ and $\mathrm{R}$ plots (M-W $\mathrm{U}, \mathrm{p}>0.05$; Table 1 ). The irregularity of soil surface, determined as the roughness coefficient, varied between 1.04 and $1.67 \mathrm{~m} \mathrm{~m}^{-1}$. Soil surface from $\mathrm{O}$ plots shown median roughness coefficient of $1.50 \mathrm{~m} \mathrm{~m}^{-1}$. In contrast, median roughness coefficient from $\mathrm{R}$ plots was $1.17 \mathrm{~m} \mathrm{~m}^{-1}$. Bulk density varied between 1.01 and $1.67 \mathrm{~g} \mathrm{~cm}^{-3}$. Although the K-W test found significant differences among sites, these were relatively small inside $\mathrm{O}$ and $\mathrm{R}$ plot types. Generally, $\mathrm{O}$ plots showed lower bulk densities (1.01-1.30 $\mathrm{g} \mathrm{cm}^{-3}$ ) than $\mathrm{R}$ plots $\left(1.34-1.67 \mathrm{~g} \mathrm{~cm}^{-3}\right)$.

Although soil organic matter content was generally low (maximum value found was $1.98 \%$ ), medians varied significantly among sites, ranging between 1.09 (median of CR-R, CR-O and LB-R plots) and $1.53 \%$ (median of LB-O. CG-R, CG-O and LA-R plots). Although significant ( $\mathrm{M}-\mathrm{W} \mathrm{U}, \mathrm{p}<0.05$; Table 1 ), differences between $\mathrm{R}$ and $\mathrm{O}$ plot types were negligible (0.23\%).

Soil water content was below $10 \%$ in all plots $(2.74-8.93 \%$; Table 1), which is below the permanent wilting point for most soils (Ashman and Puri, 2002). Significant differences were observed between sandy loam and clayey soil plots (5.25 and 6.83\%, respectively). On the other hand, the post-hoc test did not show clear differences between plots according to their lithological substrate (Table 1). Similarly, there were significant but limited differences between $\mathrm{O}$ - and R-plots (1.48 and 1.25\%, respectively). Finally, plant cover increased significantly from R-to O-plots (4 and $6 \%$, respectively). Nevertheless, plant cover was very low in all the study plots and sites due to the intense ploughing (median 5\%, range $1-9 \%$ ). In the four study sites and the 80 plots the plant cover was negligible.

\subsection{Soil hydrological response}

Time to ponding (Tp) increased significantly from $0,82.5 \mathrm{~s}$, to $\mathrm{R}$ plots, $37 \mathrm{~s}$ (Table 2). In $\mathrm{O}$ plots, Tp ranged between 43 and $176 \mathrm{~s}$. Generally, plots from sandy loam soils showed longer Tps (141 s, CR; 103 s, LB) than those from clayey soils (51 s, CG; 56.5 s, LA). No significant differences were observed among Tps from soils from $\mathrm{R}$ plots, which varied in a shorter interval (25-49 s). Time required for runoff initiation ( $\mathrm{Tr}$ ) increased significantly from $\mathrm{R}(76 \mathrm{~s})$ to $\mathrm{O}$ plots (133.5 s) (Table 2). Although minimum median $\mathrm{Tr}$ periods were found in clayey CG plots were relatively short (85.5 s, O plots; $56 \mathrm{~s}, \mathrm{R}$ plots), the post-hoc test did not show clear differences

Table 2

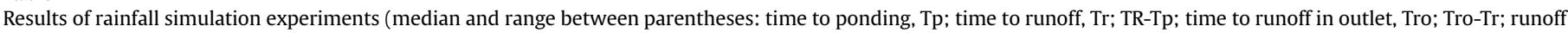

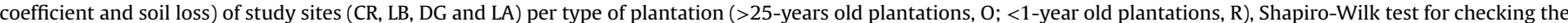

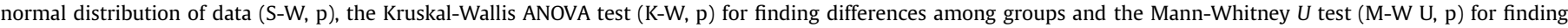
differences between $\mathrm{O}$ and $\mathrm{R}$ plots. Medians followed by the same letter within the same column are not significantly different. ND: not determined.

\begin{tabular}{|c|c|c|c|c|c|c|c|c|}
\hline Type & Site & $\mathrm{Tp}(\mathrm{s})$ & $\operatorname{Tr}(\mathrm{s})$ & $\operatorname{Tr}-\mathrm{Tp}(\mathrm{s})$ & Tro (s) & Tro-Tr (s) & Runoff coefficient (\%) & Soil loss $\left(\mathrm{Mg} \mathrm{ha}^{-1} \mathrm{~h}^{-1}\right)$ \\
\hline \multirow[t]{5}{*}{$\mathrm{O}$} & CG & $51(43,58) b c$ & $85.5(76,97)$ bc & $33(26,42)$ & $197.5(189,214) c$ & $115.5(92,125)$ & $41.26(33.9,47.98) \mathrm{a}$ & $2.794(1.135,3.494) \mathrm{a}$ \\
\hline & CR & $141.5(123,176) \mathrm{e}$ & $213(191,256) \mathrm{e}$ & $72.5(44,97)$ & $304.5(254,345) \mathrm{e}$ & $87(56,117)$ & $41.715(37.56,45.8) \mathrm{a}$ & $1.516(0.648,2.481) \mathrm{a}$ \\
\hline & LA & $56.5(52,76) \mathrm{c}$ & $128.5(121,143) \mathrm{d}$ & $68(60,77)$ & $215.5(179,254) \mathrm{c}$ & $90(50,123)$ & $42.26(35.08,49.09) \mathrm{a}$ & $2.846(0.982,3.708) \mathrm{a}$ \\
\hline & LB & $103(89,123) d$ & $140.5(133,165) \mathrm{d}$ & $38(22,45)$ & $265.5(254,312) d$ & $126.5(106,147)$ & $45.77(37.09,48.66) \mathrm{a}$ & $1.117(0.690,1.845) \mathrm{a}$ \\
\hline & All sites & $82.5(43,176)$ & $133.5(76,256)$ & $44.5(22,97)$ & $254(179,345)$ & $110(50,147)$ & $42.94(33.90,49.09)$ & $1.841(0.648,3.708)$ \\
\hline \multirow[t]{5}{*}{$\mathrm{R}$} & CG & $32.5(25,36) \mathrm{a}$ & $56(53,60)$ a & $23(18,31)$ & $82(76,99) \mathrm{a}$ & $26(21,42)$ & $78.10(70.76,79.87) \mathrm{c}$ & $16.782(7.951,19.899) \mathrm{c}$ \\
\hline & $\mathrm{CR}$ & $44(39,49) \mathrm{ab}$ & $86.5(82,99) \mathrm{c}$ & $45.5(39,54)$ & $126(115,147) b$ & $35.5(26,57)$ & $66.65(64.00,74.32) \mathrm{b}$ & $11.130(8.128,14.482) \mathrm{b}$ \\
\hline & LA & $37.5(32,42) \mathrm{a}$ & $66.5(59,98) b$ & $30.5(22,58)$ & $115(104,154) b$ & $49.5(36,60)$ & $76.31(71.87,78.98) \mathrm{c}$ & $14.2145(10.519,18.544) \mathrm{c}$ \\
\hline & LB & $37(28,43) \mathrm{a}$ & $77.5(59,80)$ bc & $41.5(16,51)$ & $112(97,120) b$ & $35(25,55)$ & $69.24(65.98,71.96) \mathrm{b}$ & $9.007(7.294,11.982) \mathrm{b}$ \\
\hline & All sites & $37(25,49)$ & $76(53,99)$ & $34.5(16,58)$ & $112(76,154)$ & $36.5(21,60)$ & $71.92(64.00,79.87)$ & $12.630(7.294,19.899)$ \\
\hline S-W, p & & 0.0 & $6.95 \times 10^{-12}$ & ND & $2.06 \times 10^{-7}$ & ND & $5.31 \times 10^{-12}$ & $1.22 \times 10^{-10}$ \\
\hline $\mathrm{K}-\mathrm{W}, \mathrm{p}$ & & 0 & 0 & ND & 0 & ND & $4.40 \times 10^{-12}$ & $1.48 \times 10^{-12}$ \\
\hline M-W U, p & & 0 & $1.28 \times 10^{-11}$ & ND & 0 & ND & 0 & 0 \\
\hline
\end{tabular}




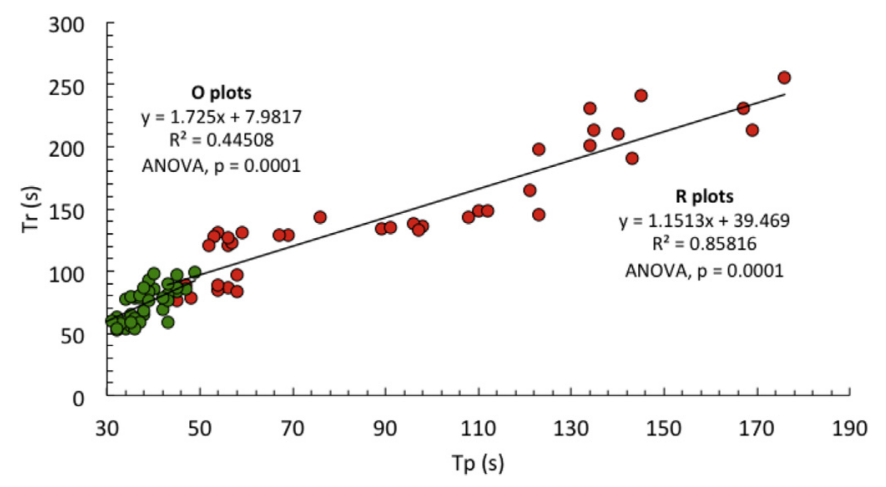

Fig. 3. Relation between time to runoff ( $\mathrm{Tr}$ ) and time to ponding (Tp) in recent and old plantations ( $\mathrm{R}$ and $\mathrm{O}$ plots, respectively).

between clayey and sandy loam soils. Tr-Tp periods varied between 34.5 ( $\mathrm{R}$ plots) and $44.5 \mathrm{~s}$ (O plots). For both $\mathrm{O}$ and $\mathrm{R}$ plots, $\mathrm{Tr}$ increased with $\mathrm{Tp}$, although the slope of the regression line was deeper in R plots (Fig. 3).

Runoff reached outlet quickly in $\mathrm{R}$ (34.5 s) than in O plots (254 s) (Table 2). In old plantations, the post-hoc test showed that Tro increased from clayey (197.5 s, CG-O; $215.5 \mathrm{~s}, \mathrm{LA}-\mathrm{O})$ to sandy loam soils (265.5 s, LB-O; 304.5 s, CR-O). On the other hand, Tro from recently planted vineyards did not vary according to soil texture, varying between $82 \mathrm{~s}$ in CG-R plot and $117.5 \mathrm{~s}$ (CR-R, LA-R and LB-R plots). Finally, Tro-Tr increased from 36.5 (R plots) to $110 \mathrm{~s}$ (O plots). Although Tro generally increased with $\mathrm{Tr}$ for $\mathrm{O}$ and $\mathrm{R}$ plots (Fig. 4), Tro was higher in $\mathrm{O}$ plots for the same $\operatorname{Tr}$ values.

When all cases were considered together, positive significant correlations were found between $\mathrm{Tp}, \mathrm{Tr}$ and Tro and roughness index (Table 3). These variables were also significantly and negatively correlated with bulk density (Table 3). No significant correlations were found between times of response and other soil surface variables. No differences were found among median runoff coefficients from soils with different parent material (M-W U, $\mathrm{p}>0.05$ ). According to post-hoc results, the median runoff rate from $\mathrm{R}$ plots varied between clayey (CG-R and LA-R plots, 76.77\%) and sandy loam soils (CR-R and LB-R plots, 68.26\%). On the other hand, no significant differences were found among runoff coefficients from different $O$ plots. Independently of lithology, runoff coefficient decreased significantly from R, $71.92 \%$, to O plots, $42.94 \%$ (Table 2). Runoff coefficient was significantly correlated with roughness index, Rs: -0.7147 , and bulk density, Rs: 0.7682 (Table 3).

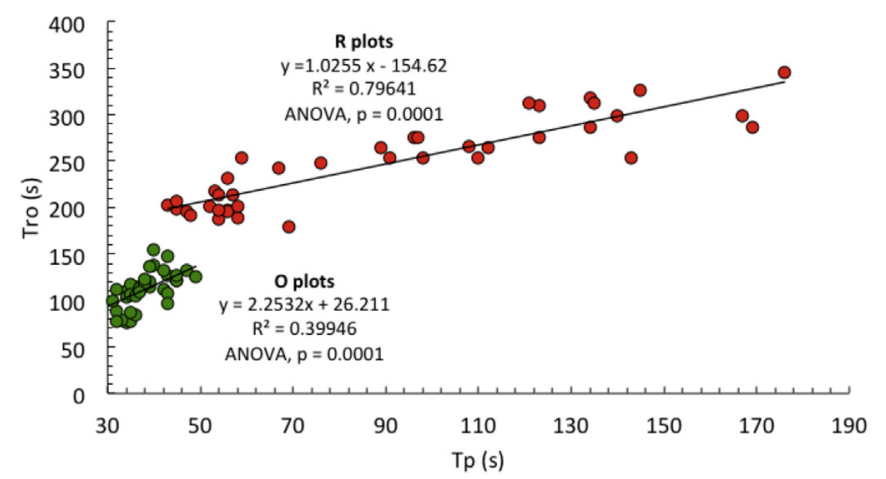

Fig. 4. Relation between time to runoff in outlet (Tro) and time to runoff ( $\operatorname{Tr}$ ) in recent and old plantations ( $\mathrm{R}$ and $\mathrm{O}$ plots, respectively).

\subsection{Soil erosion}

No differences were found among median soil loss from different parent materials. No significant differences were observed among soil loss values from 0 plots, which varied between 0.65 and 3.71 $\mathrm{Mg} \mathrm{ha}{ }^{-1} \mathrm{~h}^{-1}$ (median: $1.84 \mathrm{Mg} \mathrm{ha}^{-1} \mathrm{~h}^{-1}$; Table 2). In R plots, soil loss varied between clayey (CG-R and LA-R plots, $14.99 \mathrm{Mg} \mathrm{ha}^{-1}$ $\mathrm{h}^{-1}$ ) and sandy loam soils (CR-R and LB-R plots, $9.71 \mathrm{Mg} \mathrm{ha}^{-1} \mathrm{~h}^{-1}$ ). No significant differences were found among soil losses from plots under old plantations. Although runoff rate increased by $67.5 \%$ from $\mathrm{O}$ to R plots (42.94 and $71.92 \%$, respectively), soil loss increased by $586 \%$ ( 1.84 and $12.63 \mathrm{Mg} \mathrm{ha}^{-1} \mathrm{~h}^{-1}$; Table 2). Soil erosion from $\mathrm{O}$ plots increased strongly with the runoff coefficient (Fig. 5), with values ranging between approximately 8.2 (for runoff rate $65 \%$ ) and $17.4 \mathrm{Mg} \mathrm{ha}^{-1} \mathrm{~h}^{-1}$ (for $80 \%$ ). In contrast, soil erosion from $\mathrm{O}$ plots stayed always below $5 \mathrm{Mg} \mathrm{ha}^{-1} \mathrm{~h}^{-1}$ and did not increase with runoff rate.

\section{Discussion}

The experiments carried out in this research showed that soil hydrological response to simulated rainfall from vineyard soils varies largely between old ( $>50$ years) and recent $(<1$ year) vine plantations at plot scale. Among other factors, Mediterranean vineyards are characterized by poor organic matter contents (Muñoz-Rojas et al., 2012; Novara et al., 2011). Partly, this is a consequence of climatic conditions and this trend is expected to grow in the context of global warming (Muñoz-Rojas et al., 2013). Our research brings relevant information for the research about soil organic matter (Yigini and Panagos, 2016) as planting results in soils with low soil organic and high erosion rates, which results in the removal of soil organic matter particles and then initiate a process of soil degradation.

Different authors have demonstrated that rock fragments contribute to delayed ponding and runoff initiation. In Mediterranean soils, Zavala et al. (2010) observed that enhanced infiltration rates are partly due to increased roughness of the soil surface caused by rock fragments. They observed that rock fragments channel the water flow between them and generate deeper, more hydraulically efficient flow. This causes greater pressure of the water column and favors infiltration. Microtopography of the soil surface is a key factor for soil erosion at small scales. Low roughness coefficients may be associated to low rock fragment cover and soil sealing. In our experiments, the soil surface requires $45 \mathrm{~s}$ (median of all values) to get ponded and $87 \mathrm{~s}$ for runoff to initiate. Recently planted vineyards, with higher bulk densities and lower roughness coefficients showed relatively short Tp and Tr periods (37 and $76 \mathrm{~s}$, respectively), with only $112 \mathrm{~s}$ (median) required for runoff flow to reach the outlet (Tro). Runoff flow connectivity was lower in $\mathrm{O}$ plots, with longer median Tr-Tp and Tro-Tr periods (45 and $110 \mathrm{~s}$, respectively) than R plots ( 35 and $37 \mathrm{~s}$ ). This is especially important for rainstorms shorter than Tro periods, which cannot produce surface wash and consequently no soil losses. Longer rainstorms will produce runoff flow and soil loss. Differences between paired $O$ and $\mathrm{R}$ plots show a clear impact of the age of vine plantations on accelerated soil erosion risk.

Times of response to simulated rainfall (Tp, Tr and Tro) were conditioned by soil bulk density and surface roughness coefficient too. Relatively low bulk density in O plots (median $1.13 \mathrm{~g} \mathrm{~cm}^{-3}$ ) and, consequently, higher porosity contributed to accelerate time required for ponding in $\mathrm{O}$ plots. Soils from $\mathrm{R}$ plots were more compacted (bulk density, $1.45 \mathrm{~g} \mathrm{~cm}^{-3}$ ). This led to relatively low infiltration rates at the beginning of rainfall simulations and fast ponding. In these conditions, runoff initiated quickly in $\mathrm{R}$ plots (median $76 \mathrm{~s}$ ) in contrast to O plots (median $133.5 \mathrm{~s}$ ). Other authors 
Table 3

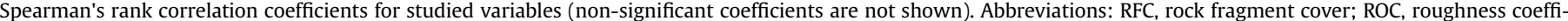

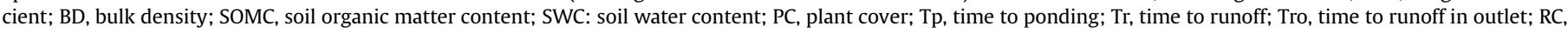
runoff coefficient; SE, soil erosion.

\begin{tabular}{|c|c|c|c|c|c|c|c|c|c|c|}
\hline & ROC & RFC & $\mathrm{BD}$ & SOMC & SWC & PC & $\mathrm{Tp}$ & $\operatorname{Tr}$ & Tro & $\mathrm{RC}$ \\
\hline $\mathrm{BD}$ & $-0.7823^{\mathrm{a}}$ & & & & & & & & & \\
\hline SOMC & $0.3446^{c}$ & $-0.4894^{\mathrm{a}}$ & $-0.2916^{c}$ & & & & & & & \\
\hline SWC & $0.3429^{c}$ & $-0.6710^{\mathrm{a}}$ & $-0.2243^{d}$ & $0.5818^{a}$ & & & & & & \\
\hline PC & $0.3486^{c}$ & $-0.3754^{\mathrm{b}}$ & $-0.3262^{c}$ & $0.4992^{\mathrm{a}}$ & $0.5345^{\mathrm{a}}$ & & & & & \\
\hline $\mathrm{Tp}$ & $0.6836^{a}$ & $0.3386^{c}$ & $-0.7591^{\mathrm{a}}$ & & & $0.2570^{\mathrm{d}}$ & & & & \\
\hline $\mathrm{Tr}$ & $0.5980^{\mathrm{a}}$ & $0.3990^{b}$ & $-0.6248^{a}$ & & & & $0.9246^{\mathrm{a}}$ & & & \\
\hline Tro & $0.6924^{\mathrm{a}}$ & $0.3205^{c}$ & $-0.7385^{a}$ & & & $0.2480^{\mathrm{d}}$ & $0.9415^{\mathrm{a}}$ & $0.9297^{\mathrm{a}}$ & & \\
\hline $\mathrm{RC}$ & $-0.7147^{a}$ & & $0.7682^{\mathrm{a}}$ & & & $-0.3123^{c}$ & $-0.8170^{a}$ & $-0.7378^{a}$ & $-0.8035^{a}$ & \\
\hline SE & $-0.7315^{a}$ & $-0.4046^{\mathrm{b}}$ & $0.7976^{\mathrm{a}}$ & & & & $-0.8586^{\mathrm{a}}$ & $-0.7952^{a}$ & $-0.8439^{a}$ & $0.8879^{a}$ \\
\hline
\end{tabular}

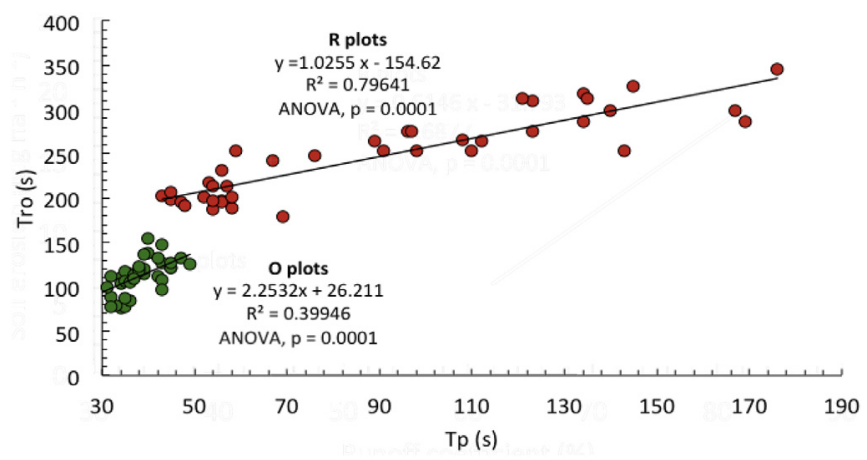

Fig. 5. Relation between soil erosion and runoff coefficient in recent and old plantations ( $\mathrm{R}$ and $\mathrm{O}$ plots, respectively). No significant relation was found between both variables in $\mathrm{O}$ plots.

have observed low sediment transport in old vineyards (35 years), with relatively high organic matter content and bulk density, in contrast to young ones (2 years) (Rodrigo Comino et al., 2015). In the study sites at Les Alcusses valley in Valencia, the key factor is the soil roughness that is low in recently planted vineyards and much higher in the old ones due to the tillage.

Recently planted vineyards ( $>1$ year) on different substrates are prone to very high soil and water losses. On the other hand, old plantations showed a very low soil erosion rates under the same conditions. Despite the higher frequency of low-intensity rainstorms, most of soil erosion and water losses in Mediterranean areas are observed after high-intensity rainfall (Rodrigo Comino et al., 2016d). Different authors have reported the relevance of studying extreme rainstorms for planning soil erosion control measures. This research demonstrates that when a combination of recently planted vineyards and extreme rainfall events take place the soil erosion rates are non-sustainable. The age of the vineyards was key to explain the contrasted soil erosion rates found. From median values, soil loss from $\mathrm{O}$ plots produced $14.6 \%$ of soil loss (1.84 $\mathrm{Mg} \mathrm{ha}^{-1} \mathrm{~h}^{-1}$ ) observed in R plots (12.63 $\mathrm{Mg} \mathrm{ha}^{-1} \mathrm{~h}^{-1}$; Table 2). Long-term ploughing in traditional vineyards contributed to reduced water and sediment connectivity, especially after reduction of soil bulk density and increased roughness of the soil surface. This is also a consequence of the sediment exhaustion after the plantation, as the plantation works generate sediments available and create a detachment control erosion mechanism. After some years, the exhaustion of the fresh material generated by the plantation resulted in a sediment-control erosion mechanism. This is in agreement with other authors who have concluded that soil management determines the hydrological response of agricultural soils (Romero-Díaz et al., 2017; Wang et al., 2015). In NE Spain, CotsFolch et al. (2009) reported that new vineyards require hillslope terracing and the use of heavy machinery, which results in the alteration of original soil, natural drainage and landscapes, and they increase soil erosion.

It has been reported that scaling up from plot to catchment level causes underestimation of erosion rates (Raclot et al., 2009). Morvan et al. (2014) concluded that soil loss rates estimated from $0.25 \mathrm{~m}^{2}$ (as in our study) are not valid to larger scales as vineyard or catchment, even under the same conditions (Chaplot and Le Bissonnais, 2000). In addition, upscaling runoff rates may result in overestimation because of the complexity of the spatial distribution of runoff generation/infiltration patches at large scales (Van de Giesen et al., 2000). This is why our research focuses on the detachment of materials and the initiation of the runoff, which shed light about landscape connectivity (Keesstra et al., 2014; Masselink et al., 2017).

Although soil erosion rates reported in Mediterranean vineyards depend largely on determination methods and temporal and spatial scales, it is generally considered that soil erosion rates are high. At plot scale and rainfall intensities between 20 and $117 \mathrm{~mm} \mathrm{~h}^{-1}$, soil erosion rates vary in a wide range (Rodrigo Comino et al., 2016b). Among others, some reported rates are 0.04 (Morvan et al., 2014), 0.39 (Arnáez et al., 2007), 1.01 (Blavet et al., 2009) or $2.52 \mathrm{Mg} \mathrm{ha}^{-1} \mathrm{~h}^{-1}$ (Wainwright (1996). Especially in $\mathrm{R}$ plots, observed soil loss rates are clearly above these values. This makes necessary to consider soil erosion protection measures, with special interest in recent vine plantations. Under appreciable plant cover, rock fragments and slope have a negligible impact on runoff flow (García-Díaz et al., 2017). In contrast, in bare soils, rock fragment cover and slope are among the main factors conditioning runoff and soil erosion rates in conventional vineyards (Rodrigo Comino et al., 2016c). Ramos et al. (2007) suggested that terracing systems with vines planted in long risers with low slope angles and benches only used as paths are efficient tools to decrease soil erosion risk. Nevertheless, terraced areas often require maintaining and associated infrastructures with deep effects on water flow triggering and soil erosion. Despite traditional soil erosion control measures as terracing, sediment fences, check dams and other infrastructures, different authors have proposed effective low-impact methods. Romero-Díaz et al. (2017) reported that patchy distribution of soil uses and abandoned soils leads to a reduction of soil erosion risk and higher biodiversity. The spatial distribution of runoff generation and infiltration areas may help to reduce soil erosion risk at scales larger than plot (hillslope or catchment scales). Spatial alternation of soil management types, uses or 
different-aged plantations may contribute to disconnect water and sediment fluxes through the hillslopes. Other interventions include agriculture terraces, implementation of grass margins and contour farming on slopes steeper than $10 \%$. The use of cover crops and litter also contribute to reduce the soil losses and provide ecosystems services (Mol and Keesstra, 2012; Galati et al., 2016; ParrasAlcántara et al., 2016).

Soil erosion may be also controlled by managing soil cover Corti et al. (2011) reported that grass cover was effective for soil slopes of about $15 \%$. This should help to control erosion risk in vineyards with slope gradients above that threshold (especially in $\mathrm{R}$ plots studied in this work). Other authors have strongly highlighted the efficiency of mulch. Mulching is an effective technique to improve physical properties of agricultural soils and reduce soil erosion risk (Jordán et al., 2010). Although different types of mulch materials exist (Jordán et al., 2011), wheat or barley straw mulches are particularly effective in reducing both soil erosion and runoff, in contrast to other materials (Giménez-Morera et al., 2010). A mulch layer contributes to increase the roughness of the soil surface and the interception of raindrops, delaying ponding and runoff generation and enhancing water infiltration in soils under ligneous crops (Jordán et al., 2010). Prosdocimi et al. (2016b) reported that a barley straw mulch layer caused a strong reduction of soil and water losses immediately after application on vineyards.

\section{Conclusions}

Plantation of new vineyards largely impacted runoff rates and soil erosion risk in the short term. After one year, recently planted vineyards show higher runoff and soil erosion rates than older ones under simulated rainfall. The impact of recent plantations in physical properties of the topsoil (mainly increased bulk density and lower roughness) resulted in increased water and sediment connectivity. In addition, soil plots from recently planted vineyards showed enhanced runoff rates and non-sustainable soil losses, which inform of the need to apply strategies to reduce soil losses during the plantation of vineyards and the year after.

\section{Acknowledgements}

This paper is part of the results of research projects GL200802879/BTE, LEDDRA 243857 and RECARE-FP7 (ENV.2013.6.2-4, http://recare-project.eu/).

\section{References}

Arnáez, J., Lasanta, T., Ruiz-Flaño, P., Ortigosa, L., 2007. Factors affecting runoff and erosion under simulated rainfall in Mediterranean vineyards. Soil \& Tillage Res. 93, 324-334. http://dx.doi.org/10.1016/j.still.2006.05.013.

Ashman, M.R. Puri, G., 2002. Essential Soil Science: a Clear and Concise Introduction to Soil Science. Blackwell Publishing, Oxford and Malden, MA.

Blavet, D., De Noni, G., Le Bissonnais, Y., Leonard, M., Maillo, L., Laurent, J.Y., Asseline, J., Leprun, J.C., Arshad, M.A., Roose, E., 2009. Effect of land use and management on the early stages of soil water erosion in French Mediterranean vineyards. Soil \& Tillage Res. 106, 124-136. http://dx.doi.org/10.1016/ j.still.2009.04.010.

Castillo, F.E., Ruiz Beltrán, L., 1979. Precipitaciones máximas en España. M.o de Agricultura, Madrid, Spain, 575 pp + maps.

Chaplot, V., Le Bissonnais, Y., 2000. Field measurements of interrill erosion under different slopes and plot sizes. Earth Surf. Process. Landforms 25, 145-153. http://dx.doi.org/10.1002/(SICI)1096-9837(200002)25, 2<145::AIDESP51>3.0.CO;2-3.

Corti, G., Cavallo, E., Cocco, S., Biddoccu, M., Brecciaroli, G., Agnelli, A., 2011. Evaluation of erosion intensity and some of its consequences in vineyards from two hilly environments under a Mediterranean type of climate, Italy. In: Godone, D., Stanchi, S. (Eds.), Soil Erosion Issues in Agriculture, InTech, pp. 113-160. http:// dx.doi.org/10.5772/25130.

Cots-Folch, R., Martínez-Casasnovas, J.A., Ramos, M.C., 2009. Agricultural trajectories in a Mediterranean mountain región (Priorat, NE Spain) as a consequence of vineyard conversión plans. Land Degrad. Dev. 20, 1-13. http://dx.doi.org/

\section{$10.1002 / 1 d r .856$.}

Galati, A., Crescimanno, M., Gristina, L., Keesstra, S., Novara, A., 2016. Actual provision as an alternative criterion to improve the efficiency of payments for ecosystem services for $C$ sequestration in semiarid vineyards. Agric. Syst. 144, 58-64. http://dx.doi.org/10.1016/j.agsy.2016.02.004.

García-Díaz, A., Bienes, R., Sastre, B., Novara, A., Gristina, L., Cerdà, A., 2017. Nitrogen losses in vineyards under different types of soil groundcover. A field runoff simulator approach in central Spain. Agric. Ecosyst. Environ. 236, 256-267. http://dx.doi.org/10.1016/j.agee.2016.12.013.

Giménez-Morera, A., Ruiz Sinoga, J.D., Cerdà, A., 2010. The impact of cotton geotextiles on soil and water losses from Mediterranean rainfed agricultural land. Land Degrad. Dev. 21, 210-217. http://dx.doi.org/10.1002/ldr.971.

Jordán, A., Zavala, L.M., Gil, J., 2010. Effects of mulching on soil physical properties and runoff under semi-arid conditions in southern Spain. Catena 81, 77-85. http://dx.doi.org/10.1016/j.catena.2010.01.007.

Jordán, A., Zavala, L.M., Muñoz-Rojas, M., 2011. Mulching, effects on soil physical properties. In: Glinski, J., Horabik, J., Lipiec, J. (Eds.), Encyclopedia of Agrophysics. Springer, Dordrecht, pp. 492-496. http://dx.doi.org/10.1007/978-90481-3585-1_275.

Keesstra, S., Pereira, P., Novara, A., Brevik, E.C., Azorin-Molina, C., ParrasAlcántara, L., Jordán, A., Cerdà, A., 2016. Effects of soil management techniques on soil water erosion in apricot orchards. Sci. Total Environ. 551-552, 357-366. http://dx.doi.org/10.1016/j.scitotenv.2016.01.182.

Keesstra, S.D., Temme, A.J.A.M., Schoorl, J.M., Visser, S.M., 2014. A new, simple model for temporal and spatial sediment fluxes in meso-scale catchments: LAPSUS-D: the hydrological functioning. Geomorphology 212, 97-107.

Kirchhoff, M., Rodrigo Comino, J., Seeger, M., Ries, J.B., 2017. Soil erosion in sloping vineyards under conventional and organic land use managements (Saar-Mosel valley, Germany). Cuad. Investig. Geográfica 43, 119-140. http://dx.doi.org/ $10.18172 /$ cig. 3161.

Martínez-Casasnovas, J.A., Ramos, M.C., Ribes-Dasi, M., 2005. On-site effects of concentrated flow erosion in vineyard fields: some economic implications. Catena 60 (2), 129-146.

Masselink, R., Temme, A.J.A.M., Giménez, R., Casalí, J., Keesstra, S.D., 2017. Assessing hillslope-channel connectivity in an agricultural catchment using rare-earth oxide tracers and random forests models. Cuad. Investig. Geográfica 43, 19-39. http://dx.doi.org/10.18172/cig.3169.

Mol, G., Keesstra, S.D., 2012. Soil science in a changing world. Curr. Opin. Environ. Sustain. 4, 473-477.

Morvan, X., Naisse, C., Malam Issa, O., Desprats, J.F., Combaud, A., Cerdan, O., 2014 Effect of ground-cover type on surface runoff and subsequent soil erosion in Champagne vineyards in France. Soil Use Manag. 30, 372-381. http:// dx.doi.org/10.1111/sum.12129.

Muñoz-Rojas, M., Jordán, A., Zavala, L.M., De la Rosa, D., Abd-Elmabod, S.K., AnayaRomero, M., 2012. Organic carbon stocks in Mediterranean soil types under different land uses (Southern Spain). Solid Earth. 3, 375-386. http://dx.doi.org/ 10.5194/se-3-375-2012.

Muñoz-Rojas, M., Jordán, A., Zavala, L.M., González-Peñaloza, F.A., De la Rosa, D. Pino-Mejías, R., Anaya-Romero, M., 2013. Modelling soil organic carbon stocks in global change scenarios: a CarboSOIL application. Biogeosciences 10 8253-8268. http://dx.doi.org/10.5194/bg-10-8253-2013.

Novara, A., Gristina, L., Saladino, S.S., Santoro, A., Cerdà, A., 2011. Soil erosion assessment on tillage and alternative soil managements in a Sicilian vineyard. Soil \& Tillage Res. 117, 140-147. http://dx.doi.org/10.1016/j.still.2011.09.007.

Parras-Alcántara, L., Lozano-García, B., Keesstra, S., Cerdà, A., Brevik, E.C., 2016 Long-term effects of soil management on ecosystem services and soil loss estimation in olive grove top soils. Sci. Total Environ. http://dx.doi.org/10.1016/ j.scitotenv.2016.07.016.

Prosdocimi, M., Cerdà, A., Tarolli, P., 2016a. Soil water erosion on Mediterranean vineyards: a review. Catena 141, 1-21. http://dx.doi.org/10.1016 j.catena.2016.02.010.

Prosdocimi, M., Jordán, A., Tarolli, P., Keesstra, S., Novara, A., Cerdà, A., 2016b. The immediate effectiveness of barley straw mulch in reducing soil erodibility and surface runoff generation in Mediterranean vineyards. Sci. Total Environ. 547, 323-330. http://dx.doi.org/10.1016/j.scitotenv.2015.12.076.

Raclot, D., Le Bissonnais, Y., Louchart, X., Andrieux, P., Moussa, R., Voltz, M., 2009. Soil tillage and scale effects on erosion from fields to catchment in a Mediterranean vineyard area. Agric. Ecosyst. Environ. 134, 201-210. http://dx.doi.org/ 10.1016/j.agee.2009.06.019.

Ramos, M.C., Cots-Folch, R., Martínez-Casasnovas, J.A., 2007. Sustainability of modern land terracing for vineyard plantation in a Mediterranean mountain environment - the case of the Priorat region (NE Spain). Geomorphology 86, 1-11. http://dx.doi.org/10.1016/j.geomorph.2006.08.004.

Rodrigo Comino, J., Iserloh, Morva, X., Malam Issa, O., Naisse, C., Keesstra, S.D. Cerdà, A., Prosdocimi, M., Arnáez, J., Lasanta, T., Ramos, M.C., Marqués, M.J., Ruiz Colmenero, M., Bienes, R., Ruiz Sinoga, J.D., Seeger, M., Ries, J.B., 2016a. Soil erosion processes in European vineyards: a qualitative comparison of rainfal simulation measurements in Germany, Spain and France. Hydrology 3, 1-19. http://dx.doi.org/10.3390/hydrology3010006.

Rodrigo Comino, J., Iserloh, T., Lassu, T., Cerdà, A., Keesstra, S.D., Prosdocimi, M. Brings, C., Marzen, M., Ramos, M.C., Senciales, J.M., Ruiz Sinoga, J.D., Seeger, M. Ries, J.B., 2016b. Quantitative comparison of initial soil erosion processes and runoff generation in Spanish and German vineyards. Sci. Total Environ. 565, 1165-1174. http://dx.doi.org/10.1016/j.scitotenv.2016.05.163.

Rodrigo-Comino, J.R., Quiquerez, A., Follain, S., Raclot, D., Le Bissonnais, Y., Casalí, J. 
Pereira, P., 2016d. Soil erosion in sloping vineyards assessed by using botanical indicators and sediment collectors in the Ruwer-Mosel valley. Agric. Ecosyst. Environ. 233, 158-170.

Rodrigo-Comino, J., Seeger, M., Senciales, J.M., Ruiz-Sinoga, J.D., Ries, J.B., 2016c Spatial and temporal variation of soil hydrological processes on steep slope vineyards (Ruwel-Mosel valley, gemany). Cuad. Investig. Geogr. 42 (1) 281-306. http://dx.doi.org/10.18172/cig.2934.

Romero-Díaz, A., Ruiz-Sinoga, J.D., Robledano-Aymerich, F., Brevik, E.C., Cerdà, A. 2017. Ecosystem responses to land abandonment in western mediterranean mountains. Catena 149, 824-835. http://dx.doi.org/10.1016/ j.catena.2016.08.013.

Sabatier, P., Poulenard, J., Fanget, B., Reyss, J.-L., Develle, A.-L., Wilhelm, B., Ployon, E. Pignol, C., Naffrechoux, E., Dorioz, J.-M., Montuelle, B., Arnaud, F., 2014. Longterm relationships among pesticide applications, mobility, and soil erosion in a vineyard watershed. Proc. Natl. Acad. Sci. 111, 15647-15652. http://dx.doi.org/ 10.1073/pnas.1411512111.

Serpa, D., Nunes, J.P., Keizer, J.J., Abrantes, N., 2017. Impacts of climate and land use changes on the water quality of a small Mediterranean catchment with intensive viticulture. Environ Pollut 224, 454-465.

StatPoint, 1982-2013. Statgraphics Centurion XVI. v. 16.02 .04 (64-bits). StatPoint Technologes, Inc, Warrenton, VA.

StatSoft, 2010. Statistica for Windows. v. 10.0. StatSoft, Inc, Tulsa, OK.
Van de Giesen, N.C., Stomph, T.J., de Ridder, N., 2000. Scale effects of Hortonian overland flow and rainfall-runoff dynamics in a West African catena landscape. Hydrol. Process. 14, 165-175.

Vaudour, E., Leclercq, L., Gilliot, J.M., Chaignon, B., 2017. Retrospective 70 y-spatial analysis of repeated vine mortality patterns using ancient aerial time series, Pléiades images and multi-source spatial and field data. Int. J. Appl. Earth Obs. Geoinformation 58, 234-248. http://dx.doi.org/10.1016/j.jag.2017.02.015.

Verheijen, F.G.A., Jones, R.J.A., Rickson, R.J., Smith, C.J., 2009. Tolerable versus actual soil erosion rates in Europe. Earth-Sci. Rev. 94, 23-38. http://dx.doi.org/10.1016/ j.earscirev.2009.02.003.

Wainwright, J., 1996. Infiltration, runoff and erosion characteristics of agricultural land in extreme storm events, SE France. Catena 26, 27-47. http://dx.doi.org/ 10.1016/0341-8162(95)00033-X.

Wang, Y., Fan, J., Cao, L., Liang, Y., 2015. Infiltration and runoff generation under various cropping patterns in the Red Soil Region of China. Land Degrad. Dev. 27, 83-91. http://dx.doi.org/10.1002/ldr.2460.

Yigini, Y., Panagos, P., 2016. Assessment of soil organic carbon stocks under future climate and land cover changes in Europe. Sci. Total Environ. 557, 838-850.

Zavala, L.M., Jordán, A., Bellinfante, N., Gil, J., 2010. Relationships between rock fragment cover and soil hydrological response in a Mediterranean environment. Soil Sci. Plant Nutr. 56, 95-104. http://dx.doi.org/10.1111/j.17470765.2009.00429.x. 